Для особых случаев может быть приглашен переводчик, что не противоречит Налоговому кодексу Российской Федерации (ст.97 НК РФ).

По результатам налоговой проверки юридическое или физическое лицо может быть привлечено к ответственности за совершение налогового правонарушения. (ст. 110 НК РФ).

Видов налоговых правонарушений достаточно много. Согласно гл. 16 Налогового кодекса РФ, одними из налоговых правонарушений являются непредставление налоговой декларации, нарушение порядка поставки на учет в налоговом органе, неуплата или неполная уплата сумм налога (сбора, страховых взносов) и другие нарушения налогового законодательства.

Для каждого нарушения предусмотрена определенная ответственность, она может быть налоговой, административной или уголовной. Разновидностью ответственности за совершение налогового правонарушения может признаваться штраф, арест, лишение свободы, лишение права на должность или деятельность [1].

Например, согласно п.1 ст. 129.1 НК РФ, за неправомерное несообщение лицом сведений, которые это лицо должно сообщить налоговому органу, предусмотрено взыскание штрафа в размере 5000 рублей.

$$
* * *
$$

1. Налоговый кодекс Российской Федерации (часть первая) от 31.07.1998 №146 - Ф3 (ред. от 20.07.2020) (с изм. и доп., вступ. в силу с 01.10.2020)

2. Письмо ФНС России от 25.07.2013 N AC-4-2/13622 (с изм. от 15.01.2019) "О рекомендациях по проведению выездных налоговых проверок"

3. Крохина, Ю. А. Налоговое право: учебник для вузов / Ю. А. Крохина. - 9-е изд., перераб. и доп. - Москва: Издательство Юрайт, 2020. - 464 с.

4. Ордынская, Е. В. Организация и методика проведения налоговых проверок: учебник и практикум для вузов / Е. В. Ордынская. - 3-е изд., перераб. и доп. - Москва: Издательство Юрайт, 2020. $448 \mathrm{c.}$

5. Тедеев, А. А. Налоговое право России: учебник для вузов / А. А. Тедеев, В. А. Парыгина. - 7-е изд., перераб. и доп. - Москва: Издательство Юрайт, 2020. - 390 с.

6. Фархутдинов, Р. Д. Налоговое право: учебное пособие для вузов / Р. Д. Фархутдинов. - Москва: Издательство Юрайт, 2020. - 177 с.

\title{
Тимофеев К.О. \\ Формы государственной поддержки студентов на региональном уровне в Чувашской республике
}

ФГБОУ ВО «Чувашский государственный педагогический университет им. И. Я. Яковлева»

doi: $10.18411 / l j-02-2021-106$

(Россия, Чебоксары)

idsp: ljournal-02-2021-106

\section{Аннотация}

В данной статье рассмотрены основные формы государственной поддержки студентов на региональном уровне в Чувашской республике с целью изучить уровень осведомленности студентов Чувашского государственного педагогического университета им. И. Я. Яковлева о данных формах с последующей возможностью каждого лично использовать тот или иной вид государственной поддержки.

Ключевые слова: формы поддержки, выплаты, студенты, социальная поддержка, материальная поддержка, стипендия.

\section{Abstract}

This article discusses the main forms of state support for students at the regional level in the Chuvash Republic in order to study the level of awareness of students of the Chuvash state pedagogical University named after I. Ya. Yakovlev about these forms with the subsequent possibility of each person to use one or another type of state support. 
Keywords: forms of support, payments, students, social support, financial support, scholarships.

Существуют абсолютно разные формы поддержки для разных слоёв населения, в том числе и для такой группы как студенты. Осуществление защитных мероприятий по отношению к студенческому возрасту имеет особую значимость, поскольку в полной мере может способствовать более успешному профессиональному и личностному становлению будущих специалистов. Очень важно своевременно отслеживать и реагировать на изменения, происходящие в условиях жизни студентов, их социальной защищенности, а также выявлять положительные и отрицательные тенденции. Большой проблемой является заблуждение студентов, что существует лишь вузовская стипендия, и они не понимают куда можно обратиться в сложной ситуации. Особенно это актуально сейчас, во время затяжной пандемии, потому что не все студенты имеют возможность работать и получать образование. Поэтому особенно важно изучить данную тему и дать возможность студентам получить нужную им информацию.

Цель исследования: изучить формы государственной поддержки студентов в Чувашской республике с дальнейшей возможностью проинформировать студентов в данной теме.

Для достижения поставленной цели нам необходимо решить ряд задач:

1) Провести анкетирование среди студентов с целью изучения осведомленности студентов о формах поддержки в Чувашской республике.

2) Проанализировать анкетирование и выделить проблемные места в данной теме.

3) Изучить формы поддержки студентов в Чувашской республике и проинформировать студентов.

Материалы и методы. Анкетирование, работа с литературой.

Для исследования было проведено анкетирование студентов с целью изучить уровень знания форм поддержки в Чувашской республике и количество человек, которые реально использовали данные виды поддержки. В анкетировании приняли участие студенты ЧГПУ с абсолютно разных факультетов и курсов по личному желанию в количестве 30 человек.

В анкетировании было задано 3 вопроса, и основным был вопрос «Знаете ли вы о всех формах государственной поддержки студентов в Чувашской республике?». Результаты можно увидеть на рисунке 1.

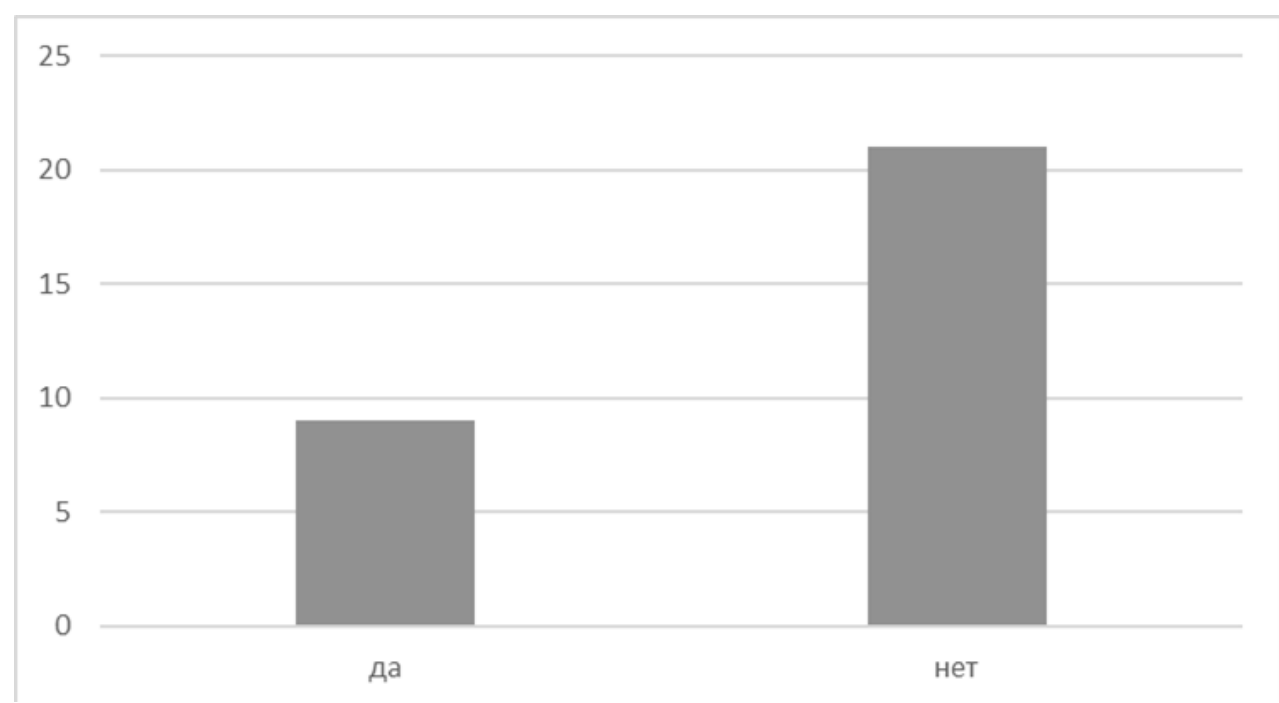

Рисунок 1- Результаты по вопросу «Знаете ли вы о всех формах государственной поддержки студентов в Чувашской республике?» 
Можно увидеть, что преимущественно студенты в количестве 20 человек не знаю всех государственных форм поддержки студентов в Чувашской республике. Остальные 10 человек знают о формах поддержки и как оказалось в дальнейшем пользовались ими.

Затем были заданы 2 вопроса для выяснения количества человек, которые пользовались различными формами поддержки, а также причины неосведомленности студентов по данной теме. Звучали они так «Пользовались ли вы когда-либо государственной поддержкой для студентов в Чувашской республике?» и «Почему вы не обращались за видами той или иной государственной поддержки в республике?». Результаты можно увидеть на рисунке 2,3 соответственно.

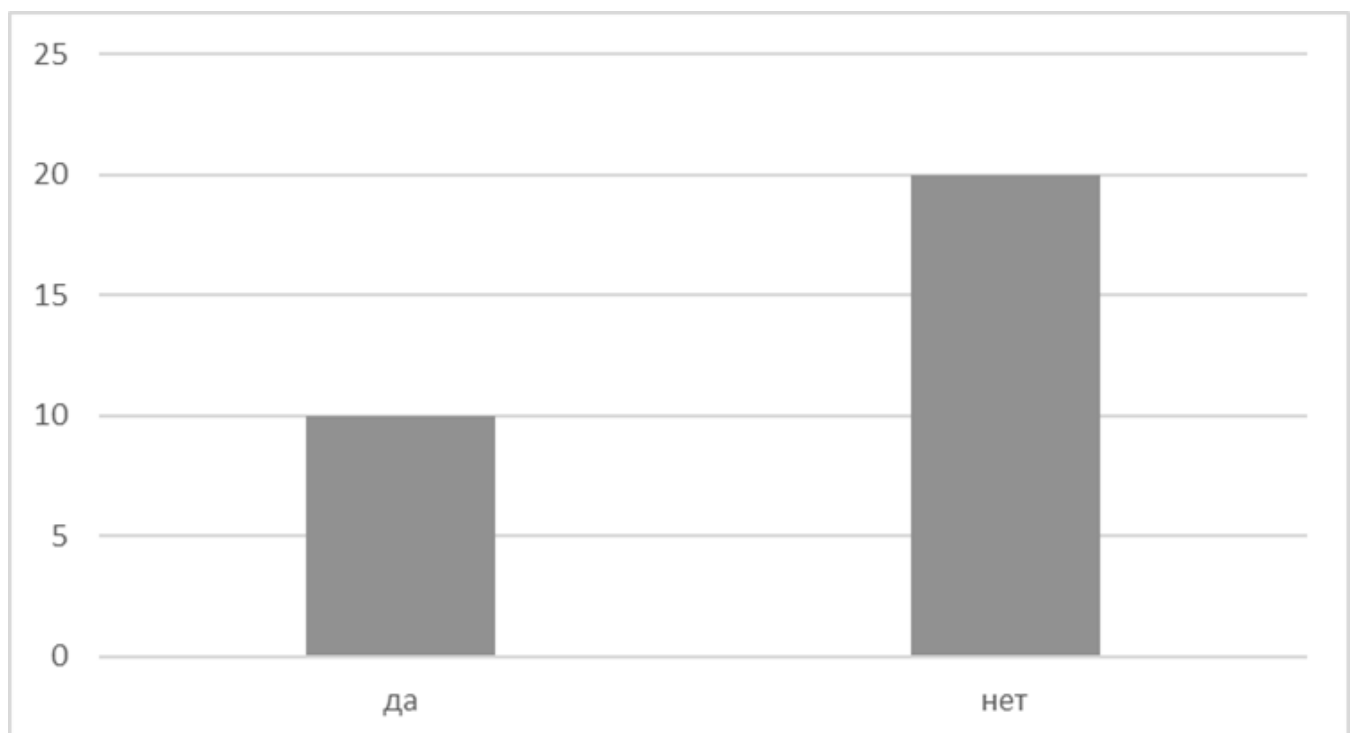

Рисунок 2- Результаты по вопросу «Пользовались ли вы когда-либо государственной поддержкой для студентов в Чувашской республике?»

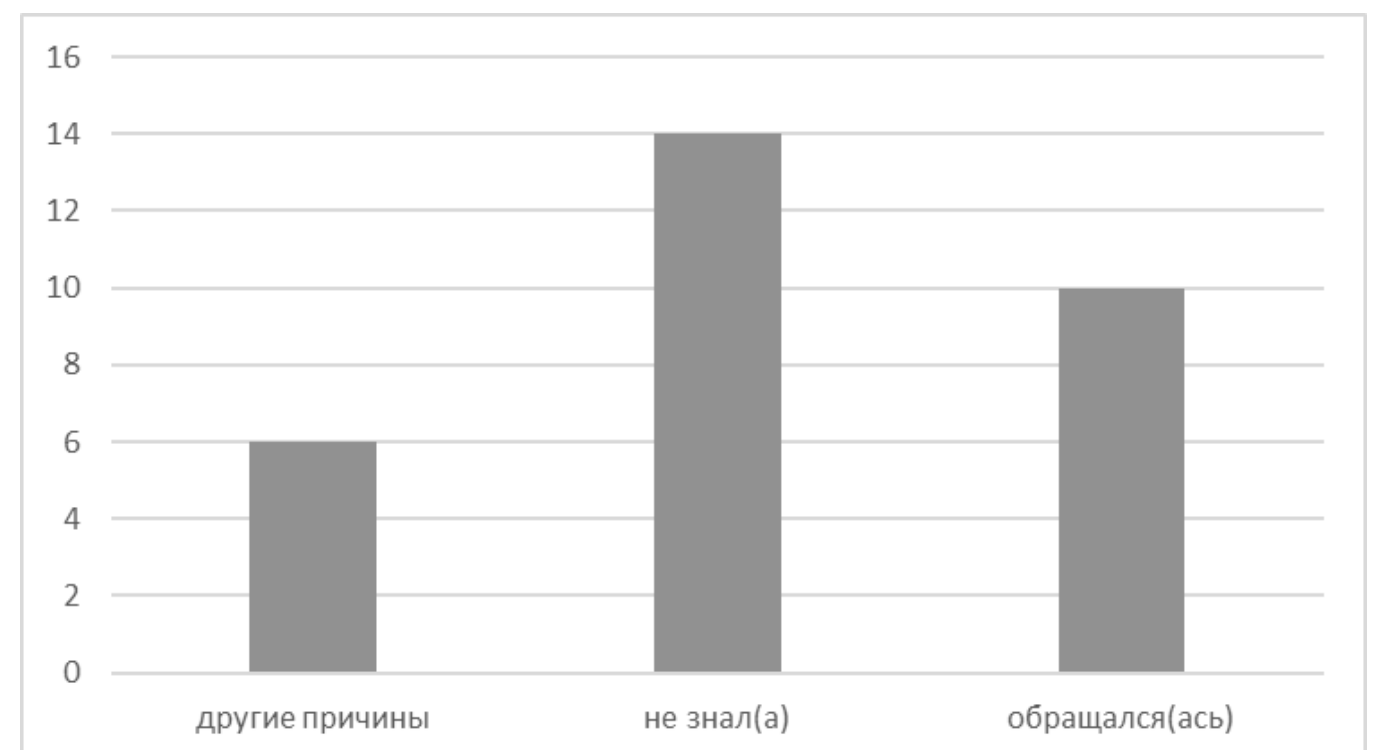

Рисунок 3- Результаты по вопросу «Почему вы не обращались за видами той или иной государственной поддержки в республике?»

Можно увидеть, что большинство не обращалось никогда за формами поддержки студентов и основной причиной является незнание данных форм. К другим причинам студенты отнесли недостаток времени или отсутсвие желания узнавать данные формы поддержки. 
Данное исследование доказывает важность и нужность статьи для студентов. Теперь основной задачей будет-изучить формы поддержки в республике и осведомить студентов о них. Для этого мы используем интернет ресурсы и литературу.

Нашлось несколько видов поддержки: материальная поддержка в виде дополнительных стипендий за активную деятельность студента, а также социальная поддержка также в виде материальных выплат. Удалось выделить следующие формы дополнительных стипендий:

1) Специальная стипендия для представителей молодежи и студентов за особую творческую устремленность- стипендия назначается Главой Чувашской Республики ежегодно к 15 января сроком на 1 год в размере, установленном указом Главы Чувашской Республики. Претендентами на получение стипендии могут быть граждане Российской Федерации, возраст которых на день подачи документов, составляет от 14 до 30 лет, достигшие значительных результатов в учебной, исследовательской, научной, творческой, производственной, управленческой, спортивной, общественной деятельности и бизнес-проектировании, проживающие на территории Чувашской Республики.

Помимо стипендии в Чувашской республике существую такие виды поддержки студентов как:

1) Условия для обучения с учетом особенностей психофизического развития и состояния здоровья, в том числе получения социально-педагогической и психологической помощи, бесплатной психолого-медико-педагогической коррекции.

2) Бесплатное пользование библиотечно-информационными ресурсами, учебной, производственной, научной базой университета.

3) Свободное пользование лечебно-оздоровительной инфраструктурой, объектами культуры и объектами спорта, установленном локальными нормативными актами вуза.

4) Обеспечение публикации работ, в изданиях вуза на бесплатной основе.

5) Снижение размера платы за пользование жилым помещением (платы за наем) и (или) размер платы за коммунальные услуги в общежитии для обучающихся или не взимать такую плату с отдельных категорий обучающихся.

Обучающимся по очной форме обучения в вузе за счет бюджетных ассигнований федерального бюджета и за счет полного возмещения расходов на обучение назначается и выплачивается:

1) Пособие по беременности и родам за период отпуска по беременности и родам.

2) Единовременное пособие женщинам, вставшим на учет в медицинских организациях в ранние сроки беременности.

Таким образом, можно сделать вывод, что студенты недостаточно знают о всех формах поддержки студентов в Чувашской республике и поэтому особо важно было изучить их, тем более их достаточно в нашей республике. Каждый, при выполнении условий, может воспользоваться любым видом поддержки в любое время.

$$
* * *
$$

1. Положение «О специальных стипендиях для представителей молодежи и студентов за особую творческую устремленность» от 15.08.2020 N 471.

2. Андреенков В.Г. Методы сбора и анализа данных // Социология / Под ред. Г.В. Осипова. М., 1996.

3. Баглай М.В., Туманов В. А. Малая энциклопедия конституционного права. М., 1999.

4. Бондарь Н.С. Права человека и местное самоуправление в Российской Федерации // Автореф. дисс. докт. юр. наук. Саратов, 1997.

5. Гусейнова Ф.Д. Студенчество: структура доходов и материальное благополучие // Социальный портрет студента. М., 2004. 